\title{
Physiochemical properties of purified Catalase enzyme from Azolla
}

\author{
S.Susmitha ${ }^{1}$, R.Shyamala Gowri ${ }^{2}$, P.Meenambigai ${ }^{2}$, R.Ramitha ${ }^{1}$ and R.Vijayaraghavan ${ }^{3} *$ \\ ${ }^{1}$ Dept. of Microbiology, Nehru Arts and Science College, T.M.Palayam, Coimbatore, \\ Tamilnadu, India \\ ${ }^{2}$ Dept. of Microbiology and Biochemistry, Nadar Saraswathy College of Arts \\ and Science, Theni, India \\ ${ }^{3}$ PSG Centre for Molecular Medicine and Therapeutics, PSG Institute of Medical \\ Sciences and Research, Coimbatore, India \\ *Corresponding author
}

\begin{abstract}
A B S T R A C T
Keywords

Antioxidant, Azolla, catalase, DEAE-Cellulose, and SDS-PAGE

Article Info

Accepted:

28 January 2016

Available Online:

10, February 2016

Enzymes are the reaction catalysts of biological systems which accelerate and direct specific biochemical reactions. Antioxidant enzymes are capable of stabilizing, or deactivating free radicals before they attack cellular components. Catalase catalyzes the reduction of hydroperoxides, thereby protecting mammalian cells against oxidative damage. The aim of the project is to analyze the presence of antioxidant enzyme and to purify the enzyme from the aquatic fern Azolla. The catalase enzyme presence was confirmed by standard assay procedure and purified through DEAE cellulose and Sephadox G-75 Column chromatography. The purified catalase enzyme was subjected for Molecular weight determination by SDS-PAGE analysis. Since the separated enzyme appeared as a single band, it was concluded that catalase enzyme as tetrameric. The purified catalase was found about 55,000 Da molecular weight. Maximum enzyme activity observed at $\mathrm{pH} 7$ which was the optimum $\mathrm{pH}$ level of the catalase enzyme purified from Azolla and the optimum temperature level was $10^{\circ} \mathrm{C}$.
\end{abstract}

\section{Introduction}

Enzymes are the reaction catalysts of biological systems which accelerate and direct specific biochemical reactions. Great specificity of enzymes is a very important biological phenomenon which assures high coordination to yield a harmonious interplay among many different metabolic activities necessary to sustain life. It is well known that activities of intracellular and extracellular enzymes depend on numerous constituents of medium or circumstances.
The most important factors which influence enzyme activity are presented by enzyme concentration, the amount of specific enzyme substrate, electrochemical reaction of medium for enzyme activity $(\mathrm{pH})$, the presence of activators (specific or nonspecific) as well as the presence of inhibitors.

Antioxidant enzymes are capable of stabilizing, or deactivating free radicals 
before they attack cellular components. They act by reducing the energy of the free radicals or by giving up some of their electrons for its use, thereby causing it to become stable. In addition, they may also interrupt with the oxidizing chain reaction to minimize the damage caused by free radicals. Catalase (E.C. 1.11.1.6; $\mathrm{H}_{2} \mathrm{O}_{2}$ : $\mathrm{H}_{2} \mathrm{O}_{2}$-oxidoreductase) belonging to the oxidoreductase family are a group of metallo enzymes with the ability to catalyze the decomposition of hydrogen peroxide into water and dioxygen. Four classes of catalases have been defined, including mono functional hem-containing catalases, catalase peroxidases, manganese catalases, and minor catalases.

CAT reacts very efficiently with $\mathrm{H}_{2} \mathrm{O}_{2}$ to form water and molecular oxygen; and with $\mathrm{H}$ donors (methanol, ethanol, formic acid, or phenols) with peroxidase activity:

\section{$2 \mathrm{H}_{2} \mathrm{O}_{2} \stackrel{\text { CAT }}{\longrightarrow} 2 \mathrm{H}_{2} \mathrm{O}+\mathrm{O}_{2}$}

$\mathrm{ROOH}+\mathrm{AH}_{2} \stackrel{\mathrm{CAT}}{\longrightarrow} \mathrm{H}_{2} \mathrm{O}+\mathrm{ROH}+\mathrm{A}$

Catalase protects cells from hydrogen peroxide generated within them. Even though CAT is not essential for some cell types under normal conditions, it plays an important role in the acquisition of tolerance to oxidative stress in the adaptive response of cells. Catalase is a tetrameric enzyme consisting of four identical tetra hedrally arranged subunits of $60 \mathrm{kDa}$ that contains a single ferri protoporphyrin group per subunit, and has a molecular mass of about $240 \mathrm{kDa}$ (Aebi, 1980). CAT reacts very efficiently with $\mathrm{H}_{2} \mathrm{O}_{2}$ to form water and molecular oxygen; and with $\mathrm{H}$ donors (methanol, ethanol, formic acid, or phenols) with peroxidase activity. Catalase catalyzes the reduction of hydroperoxides, thereby protecting mammalian cells against oxidative damage. In addition, catalase is active in neutralizing reactive oxygen species and so removes cellular superoxide and peroxides before they react with metal catalysts to form more reactive species. Catalase protects cells from hydrogen peroxide generated within them. Even though CAT is not essential for some cell types under normal conditions, it plays an important role in the acquisition of tolerance to oxidative stress in the adaptive response of cells. So our approach was to purify the catalase enzyme from Azolla and its characterization.

\section{Materials and Methods}

\section{Azolla cultivation and maintenance}

Azolla sample was collected from Tamilnadu Agricultural University, Coimbatore. About $0.5-1 \mathrm{~kg}$ of pure mother azolla culture seed material was spread uniformly over the water, after mild stirring of soil and water in the azolla bed. Fresh water was sprinkled over the azolla immediately after inoculation to make the azolla plants upright. A mixture of $20 \mathrm{~g}$ of Super Phosphate and about $1 \mathrm{~kg}$ of cow dung was added once in 5 days in order to maintain rapid multiplication of the azolla and to maintain the daily yield of $500 \mathrm{~g}$. A micronutrient mix containing magnesium, iron, copper, sulphur etc., was added at weekly intervals to enhance the mineral content of azolla. About $5 \mathrm{~kg}$ of bed soil was replaced with fresh soil, once in 30 days, to avoid nitrogen build up and prevent micronutrient deficiency. 25 to 30 percent of the water also needed to be replaced with fresh water, once every 10 days, to prevent nitrogen build up in the bed.

\section{Conditions maintained for Azolla growth}

Temperature $20^{\circ} \mathrm{C}-28^{\circ} \mathrm{C}$

Light $50 \%$ full sunlight 
Relative Humidity 65 - 80\%

Water (standing in the tank) $5-12 \mathrm{~cm}$ $\mathrm{pH}$ 4-7.5

\section{Extraction preparation}

The Azolla fern was collected from the upper position of bed and used for further enzyme purification. $10 \mathrm{~g}$ of Azolla fern was crushed with $50 \mathrm{ml}$ of cold $0.067 \mathrm{M}$ Phosphate buffer ( $\mathrm{pH} 7)$ using homogenizer.

\section{Phytochemical screening}

Phytochemical analyses were carried out according to the methods described by Trease and Evans (1989) of the crude extract of Azolla for the identification of phytochemicals like, alkaloids, saponin, steroids, flavonoids, cardiac glycosides, cynogenic glycosides and phlobatannins.

\section{Antioxidant, Protein and Phenolic Determination}

\section{Protein determination}

Protein content in the supernatant was estimated by the method described by Lowry et al. (1951). $0.2 \mathrm{ml}$ and $0.4 \mathrm{ml}$ of Azolla extract was used to determine the protein content.

\section{Total phenolic content}

The concentration of phenolic compounds in the extract was determined as described by Jayaprakasha et al. (2001) and results were expressed as tannic acids equivalents. The extracts were dissolved in a mixture of methanol and water $(6: 4 \mathrm{v} / \mathrm{v})$. Samples $(0.2$ $\mathrm{ml})$ were mixed with $1.0 \mathrm{ml}$ of tenfold diluted Folin-Ciocalteu reagents and $0.8 \mathrm{ml}$ of $7.5 \%$ sodium carbonate solution. After standing for $30 \mathrm{~min}$ at room temperature, the absorbance was measured at $765 \mathrm{~nm}$. The estimation of phenolic compounds in the fractions was carried out in triplicate and the results were averaged.

Total antioxidant content (Prieto et al. 1999)

An aliquot of each extracts $(0.05 \mathrm{ml})$ were mixed with $0.5 \mathrm{ml}$ of reagent $\left(0.6 \mathrm{M} \mathrm{H}_{2} \mathrm{SO}_{4}\right.$, $28 \mathrm{mM}$ sodium phosphate and $4 \mathrm{mM}$ ammonium molybdate) in $1.5 \mathrm{ml}$ eppendorff tube. The tubes were capped and boiled in a boiling water bath at $95^{\circ} \mathrm{C}$ for $90 \mathrm{~min}$ and cooled. The absorbance of each sample was measured at $695 \mathrm{~nm}$ against blank in a spectrophotometer. A typical blank contained $0.5 \mathrm{ml}$ of reagent solution and $0.05 \mathrm{ml}$ of buffer and treated in the same manner as test. The antioxidant capacity was expressed as micromoles of ascorbic acid equivalents of antioxidant capacity.

Catalase enzyme assay (Luck, 1974)

Catalase activity was measured spectrophotometrically by monitoring the decrease in $A_{240}$ resulting from the elimination of $\mathrm{H}_{2} \mathrm{O}_{2}$, using a Hitachi U-3210 spectrophotometer. The standard reaction mixture for the assay contained $0.067 \mathrm{M}$ potassium phosphate buffer $(\mathrm{pH} 7.0), 30 \mathrm{mM}$ $\mathrm{H}_{2} \mathrm{O}_{2}$, and $30 \mu \mathrm{l}$ of catalase-containing solution for a total volume of $3.0 \mathrm{ml}$.

On decomposition of hydrogen peroxide by catalase, the absorption decreased with time. Noted the time required for a decrease in absorbance from 0.45-0.40. The enzyme activity arrived at from this point. The extinction coefficient of hydrogen peroxide at $240 \mathrm{~nm}$ was assumed to be $0.036 \mu \mathrm{m} / \mathrm{ml}$ and one unit (U) of catalase activity was defined as the amount of enzyme required to degrade this $1 \mu \mathrm{m} / \mathrm{ml}$ of hydrogen peroxide. 
Purification of catalase enzyme (Tony ching and Gordin, 1973)

The supernatant brought to $45-90 \%$ saturation and kept at over night to precipitate the enzyme. The supernatant was centrifuged at $10,000 \mathrm{rpm}$ for $30 \mathrm{mins}$ to purify the enzyme. The purified enzyme was subjected to dialysis against $50 \mathrm{mM}$ Pottasium phosphate buffer $(\mathrm{pH}$ 7) for changing the buffer thrice at cold condition. The dialyzed sample considered as partially purified and subjected for further purification. A column (1 by $3 \mathrm{~cm})$ of DEAE-cellulose equilibrated with buffer A. Thirty milliliters of the dialyzed enzyme solution was applied to the column and washed with $4 \mathrm{ml}$ of buffer A. The column was eluted with distilled water. Active fraction detected by the standard assay method were collected and pooled for subsequent Sephadex G-75 column.

A column of $(0.5 \times 5 \mathrm{~cm})$ of sephadex G-75 that had been equilibrated with buffer $\mathrm{A}$. The active fractions $(8 \mathrm{ml})$ were diluted to $32 \mathrm{ml}$ with the buffer A in order to reduce the salt concentration.

The fraction was then applied to the column and washed with the $3 \mathrm{ml}$ of buffer A. Elution was performed with a continuous linear gradient of 0 to $0.5 \mathrm{M} \mathrm{NaCl}$ in buffer A (total volume $15 \mathrm{ml}$ ) and then with $3 \mathrm{ml}$ of $0.5 \mathrm{M} \mathrm{NaCl}$ in buffer $\mathrm{A}$. The volume of 1 fraction was $1 \mathrm{ml}$. the active fractions $(2 \mathrm{ml})$ were further purified by rechromatography on the same column and under elution conditions. Then the enzyme were stored at $4^{\circ} \mathrm{C}$ and used for the characterization of the enzyme.

\section{Molecular weight determination}

Purified catalase enzyme was subjected to sodium dodecyl sulfate polyacrylamide gel electrophoresis (SDS-PAGE) in 12\% gel as per method by Sambrook and Russel (2001) along with standard molecular weight protein markers. The sample and marker proteins were treated with $2 \%$ SDS and 5\% 2- mercaptoethanol at $100^{\circ} \mathrm{C}$ for 5 min just before loading. The gel was stained with Coomassie-brilliant blue R-250.

\section{Physio-chemical properties of catalase}

\section{Analysis of $\mathrm{pH}$ profile of catalase}

The $\mathrm{pH}$ profiles for the activity of catalase was obtained using $50 \mathrm{mM}$ Pottasium phosphate buffer ( $\mathrm{pH} 3$ to $\mathrm{pH}$ 8). In each $\mathrm{pH}$ buffer $(1 \mathrm{ml}), 30 \mu \mathrm{l}$ of enzyme solution was mixed and kept for overnight at $4^{\circ} \mathrm{C}$. After this period, enzyme activity of sample was analyzed under the standard assay condition.

\section{Analysis of thermostability of catalase}

Thirty micro liters of catalase was placed in water bath at a temperature of $10,20,30$, and $40^{\circ} \mathrm{C}$ for periods of $60 \mathrm{~min}$. Enzyme activity after treatment was analyzed under the standard assay condition.

\section{Storage stability}

Thirty microliters catalase was mixed with $1 \mathrm{ml}$ of $50 \mathrm{mM}$ Pottasium phosphate buffer (pH 7) buffer and stored at the $4^{\circ} \mathrm{C}$. Enzyme activity was analyzed every day up to 1 week in order to find out the storage stability of enzymes.

\section{Results and Discussion}

\section{Phytochemical analysis}

The extract of Azolla contains alkaloids, saponin, steroids, flavonoids, cardiac glycosides and cynogenic glycoside. Phlobatannins was absent. The observed results were tabulated (Table 1). 


\section{Protein estimation}

Standard graph was plotted for bovine serum albumin using spectrophotometric reading at $660 \mathrm{~nm}$. Total protein obtained for Azolla was $20.5 \mathrm{mg} / \mathrm{g}$ (Table 2 ).

\section{Total antioxidant and phenolic content}

The absorbance of the extract of each tube was measured for total anti oxidant content at $695 \mathrm{~nm}$ against blank it was observed that leaves contain $13.71 \mathrm{mg} / \mathrm{g}$.

The absorbance was measured at $765 \mathrm{~nm}$ for Phenolic content. The estimation of phenolic compound in the fractions was carried out in triplicate and the results were averaged. Azolla extract contained $11.56 \mathrm{mg} / \mathrm{g}$. The results were tabulated in table 2 .

\section{Catalase assay}

Catalase assay was performed for the mushroom extracts supernatant, enzyme activity were measured at $240 \mathrm{~nm}$ wavelength. Time taken for the reduction of $A_{240}$ values from $0.45-0.4$ was noticed. The enzyme activity for Azolla was $121 \mathrm{U} / \mathrm{ml}$.

\section{Purification and molecular weight of catalase from Azolla}

The enzyme eluted as a single species in the initial DEAE-cellulose chromatography step. Additional purification of the enzyme was achieved by gel filtration on Sephadex G-75. Table 3 summarizes the results of each step of the catalase purification.

The enzyme was purified about 51.07-fold, with a final specific activity of $14.3 \mathrm{U} / \mathrm{mg}$. The overall recovery of the purification was $14 \%$. The molecular mass of purified catalase was $55 \mathrm{kDa}$ (Figure 1).

\section{Effect of pH on catalase activity}

The $\mathrm{pH}$ profile on the activity of catalase enzymes from Azolla was shown in figure 2. The optimum $\mathrm{pH}$ for the strains of Azolla was $\mathrm{pH}$ 7. All the catalase enzymes had a minimum activity at $\mathrm{pH} 3.5$.

\section{Effect of temperature and storage stability of catalase activity}

Purified catalase from Azolla was stable in $50 \mathrm{mM}$ Pottasium phosphate buffer (pH 7) for more than 4 days at $4^{\circ} \mathrm{C}$, as a decrease in activity observed after 5 days (Figure 3 ). After being heated at $10-30^{\circ} \mathrm{C}$ for 60 minutes, catalase from Azolla retained 26.98 units $/ \mathrm{ml}$ of the enzyme activity measured at $30^{\circ} \mathrm{C}$ for 60 minutes but became completely inactive after treatment between $40-60{ }^{\circ} \mathrm{C}$ for 60 minutes.

\section{Storage stability of purified catalase from Azolla}

Purified catalase from Azolla was stable in Potassium phosphate buffer $(\mathrm{pH} 7)$ for more than 4 days at $4^{\circ} \mathrm{C}$, as a decrease in activity observed after 5 days (Figure 4). Azolla catalase was also completely inactive under heat treatment between $40-60^{\circ} \mathrm{C}$ for 30 minutes. This catalase enzyme has 28.08 units $/ \mathrm{ml}$ of activity after being heated at 10 $30^{\circ} \mathrm{C}$ for 60 minutes.

The main aim of analyzing the phytochemical properties of Azolla is to determine its biochemical composition. The phytochemical analysis of Azolla showed that the presence of metabolic compounds. Protein content of Azolla taken for analysis revealed that the presence of total protein. 
Table.1 Phytochemical analysis of Azolla

\begin{tabular}{|c|c|}
\hline Phytochemical constituents & Observation \\
\hline Alkaloids & + \\
\hline Steriods & + \\
\hline Saponin & + \\
\hline Cynogenic glycosides & + \\
\hline Cardiac glycosides & + \\
\hline Flavonoids & + \\
\hline Phlobatannins & - \\
\hline Phenols & + \\
\hline '+' - Present & '-'Absent
\end{tabular}

Table.2 Total anti oxidant and phenol content of Azolla

\begin{tabular}{|c|c|c|c|}
\hline $\begin{array}{c}\text { Sample } \\
\text { extraction }\end{array}$ & $\begin{array}{l}\text { Protein Content OD } \\
\text { at 660nm }(\mathbf{m g} / \mathbf{g})\end{array}$ & $\begin{array}{c}\text { Anti oxidant content } \\
\text { OD at } \mathbf{6 9 5} \mathbf{~ n m ~}(\mathbf{m g} / \mathbf{g})\end{array}$ & $\begin{array}{c}\text { Phenolic content OD } \\
\text { at 765 } \mathbf{~ n m ~}(\mathbf{m g} / \mathbf{g})\end{array}$ \\
\hline Azolla extract & 20.5 & 13.71 & 11.56 \\
\hline
\end{tabular}

Table.3 Purification of catalase from Azolla

\begin{tabular}{|c|l|c|c|c|c|c|}
\hline S.No & Purification step & $\begin{array}{c}\text { Total amount of } \\
\text { protein (mg) }\end{array}$ & $\begin{array}{c}\text { Total activity } \\
(\mathbf{U})\end{array}$ & $\begin{array}{c}\text { Specific } \\
\text { activity (U/mg) }\end{array}$ & $\begin{array}{c}\text { Recovery } \\
(\%)\end{array}$ & $\begin{array}{c}\text { Purification } \\
\text { (fold) }\end{array}$ \\
\hline 1 & Supernatant & 430 & 121 & 0.28 & 100 & 1 \\
\hline 2 & Dialyzsate & 92 & 82 & 0.89 & 67.7 & 3.1 \\
\hline 3 & DEAE- cellulose & 87 & 52 & 1.67 & 42.9 & 5.9 \\
\hline 4 & $\begin{array}{l}\text { Sephadox G-75 } \\
\text { fraction }\end{array}$ & 1.2 & 17.2 & 14.3 & 14 & 51.07 \\
\hline
\end{tabular}

Fig.1 Molecular mass of purified catalase:

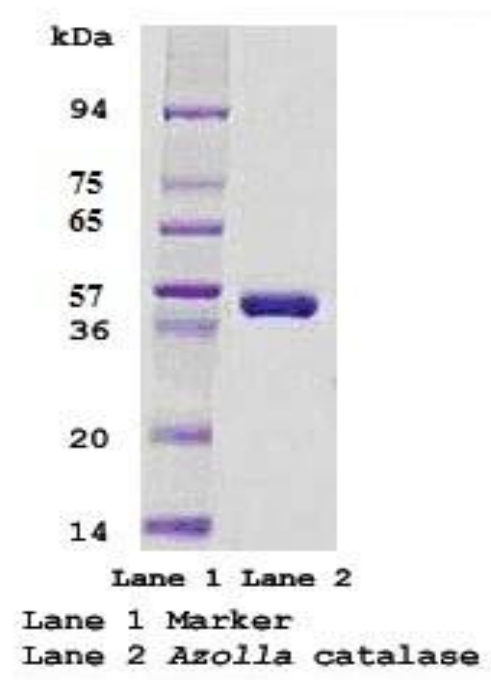


Figure 2. Effect of pH on Catalase activity

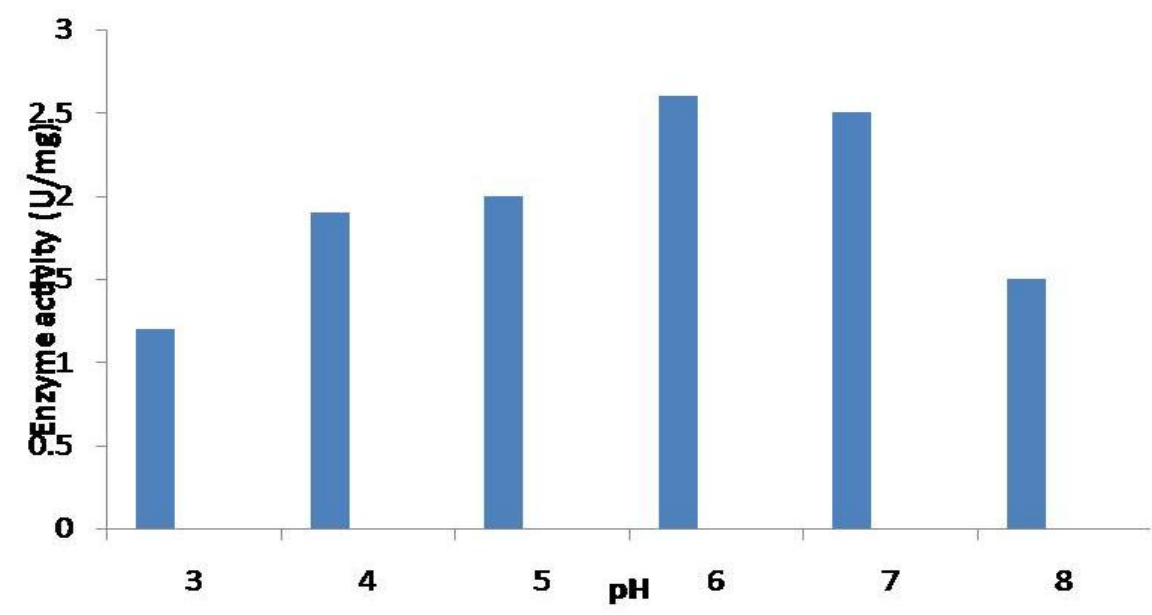

Figure 3. Temperature stability of Catalase

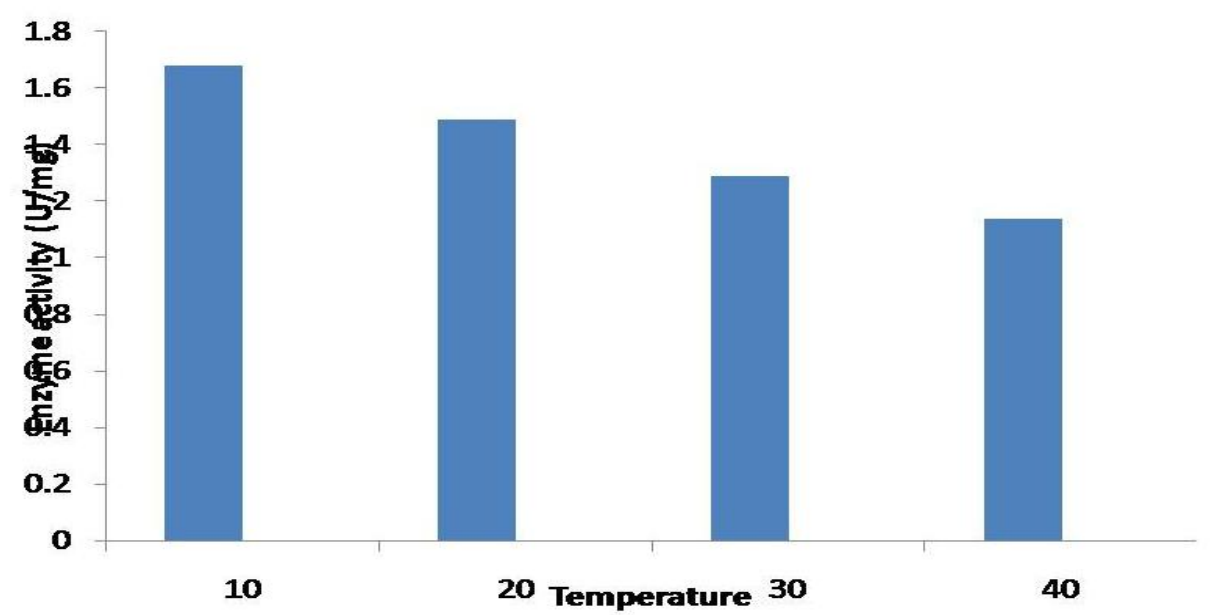

Figure 4. Storage stability of Catalase

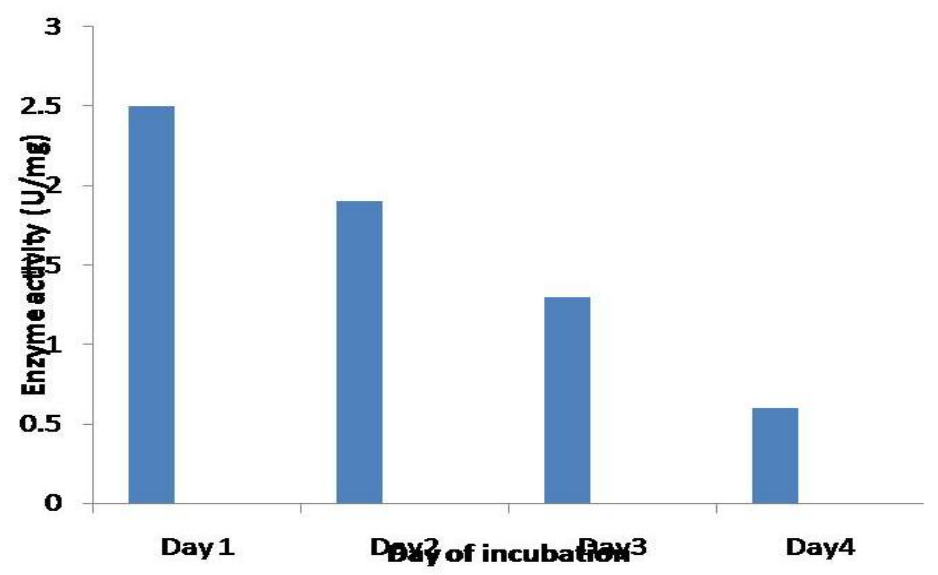


Catalase is wide spread in nature having been found in all aerobic organisms studied to date. Most of the work has been performed on the enzyme obtained from mammalian and bacterial sources where enzyme activity was present in high concentration. Previous studies had shown catalase exist in multiple forms in several plants such as tobacco, saffron, cotton, mustard, maize, wheat, sunflower, castor bean, spinach, pepper, loblolly pine and kohlrabi (Havir and McHale, 1987). Beevers, (1979) and Huang et al. (1983) reported that catalase catalyzes the decomposition of $\mathrm{H}_{2} \mathrm{O}_{2}$ produced from the $\beta$-oxidation of fatty acids. In the present study, catalase enzyme from Azolla was $12.05 \mathrm{U} / \mathrm{ml}$.

Most catalases described until now contain four equally sized subunits with each possessing a ferric heme (protoporphyrin IX), and are tetramers with a relative molecular weight in the range from 225,000 to 270,000 Da (Dunford and Stillman 1976). Although a large amount of information about the physiological function of catalase is now available (Yang and DePierre 1998), the information on the studies of catalase for amphibia has been scarce until now.

Catalase activity of Azolla was determined in the presence of hydrogen peroxide. The peak specific activity of catalase was 14.3 $\mathrm{U} / \mathrm{mg}$ observed. There was rise in specific activity in each purification step. Loewen et al. (1987) were observed the rise of specific enzyme activity in every purification step. The native PAGE method developed by Hedrick and Smith (1968) provides site estimation for proteins analyzed on gels of successive high acrylamide concentration. As it has been mentioned above, the molecular weight of catalase $\mathrm{T}$ is between 225 - $250 \mathrm{kD}$, and for catalase A considerably lower 170 - 190 kD. Ultracentrifugation studies of purified mouse hepatic catalase revealed that 5-7\% of the total material consists of a form with a higher molecular weight than the bulk of the catalase. The two components were separated by sucrose-gradient centrifugation. Polyacrylamide-gel electrophoresis (in borate buffer) demonstrated that high molecular weight catalase is enriched in a more slowly migrating component, and sodium dodecyl sulphate polyacrylamide gel-electrophoresis demonstrated that the molecular weight of the subunits of the high-molecular-weight material is identical with that of the subunits of the major form. These results suggest that high-molecularweight catalase consists of subunits that are not markedly distinct from those present in the normal catalase tetramer.

Noted that the most interesting characteristics of catalase from Azolla was the optimum $\mathrm{pH}$ and temperature. The optimum temperature and optimum $\mathrm{pH}$ for purified catalase from Azolla on enzymatic reaction were $30^{\circ} \mathrm{C}$ and $\mathrm{pH} 7$ respectively. Singh et al. (2007) studied on Archaeoglobus fulgidus, the purification, and characterization of catalase at various $\mathrm{pH}$ and found the similar $\mathrm{pH}$ characterization. Similar temperature and $\mathrm{pH}$ has also been reported by Aydemir and Kuru (2003) on catalase enzyme of blood erythrocytes.

Azolla is a small aquatic fern which floats on the water surface. It contains within its leaf cavities a symbiotic cyanobacteriumAnabaena azolae. The N-fixing capacity of Anabaena azolae enables Azolla to thrive on nitrogen-free waters. The importance of Azolla for lowland rice production has been evaluated in numerous investigations. After an investigation for several years, we found that Azolla is also a promising plant to be applied in controlled ecological life support system. 


\section{Acknowledgement}

We acknowledge our profound gratitude to the Department of Microbiology, Nehru Arts and Science College, T.M.Palayam, Coimbatore for providing the facilities for research work. We are highly indebted to Dr. B. Anirudhan (Prinicipal) Dr. J. Rathinamala, Dr. T. Balasaravanan and Dr. S. Meenatchisundaram [Associate Professors] Nehru Arts and Science College, T.M.Palayam, Coimbatore and Head, Dept. of Microbiology and Biochemistry, Associate and Asst. Professors of Nadar Saraswathy College, Theni for their valuable help to complete this work.

\section{References}

Aebi, H.E., 1980. Enzymes1: oxidoreductases, trasferases. in: bergmeyer. H,ED. Methods of enzymatic analysis. 57: 273-282.

Aydemir and Kuru. 2003. Purification and characterization of Catalase Chicken Erythrocytes and the effect of Various Inhibitors on Enzyme Activity. Turk $J$ Chem. 27: 85- 97.

Beevers, H. 1979. Microbodies in higher plants. Annu Rev Plant Physiol. 30: 159-193.

Dunford and stillman. 1976. Peroxidases and Catalases: Biochemistry, Biophysics, Biotechnology and physiology. John Wiley \& Sons. 22: 572-791.

Havir, E.A. and McHale, N.A. 1987. Biochemical and developmental characterization of multiple form of catalase in tobacco leaves. Plant Physiol. 84: 450455.

Hedrick and Smith. 1968. Size and charge separation and estimation of molecular weights of proteins by disc gel electrophoresis. Archives in Biochemistry and Biophysics. 126: 155-164.

Huang, A.H.C., Trelease, R.N., and Moore, T.S. 1983. Plant Peroxisomes. Academic Press. New York.

Jayaprakash, G.K., Singh, R.P. and Sakariah, K.K. 2001. J.Agric Food Chem. 55: 10181022.

Loewen, J. Switala, M. Smolenski, B.L. and Triggs-Raine. 1987. Biochem Cell Biol. 68:1037-1044.

Lowry, O.H., Rosebrough, N.J., Farr, A.L. and Randall, R.J. 1951. Protein measurement with Folin phenol reagent. J.Biol.chem. 193: 265.

Luck, J. 1974. In : Methods in Enzymatic Analysis, Academic Press, New York. 2: 885

Prieto, P., Prenda, M., and Aguilar, M. 1999. Spectrophotometric quantification of antioxidant capacity though the formation of a phosphomolybdenum complex: Specific application to the determination of vitamin E. Anal. Biochem. 269: 337-341.

Sambrook, J., Russel, D.W. 2001. Molecular Cloning: A Laboratory Manual. Cold Spring Harbor Laboratory Press, New York.

Singh et al., 2007. Purification and characterization of an intracellular catalaseperoxidasefrom Penicillium simplicissimum. Eur. J. Biochcm. Plant Physiology Preview. 235: $192-198$

Tony ching, M.S. and Gordin, K. 1973. Purification and properties of the Catalase of Bakers's yeast. The journal of Biological chemistry. 248: 2880-289.

Trease, G.E., and Evans, W.C. 1989. Pharmacognosy. London: $13^{\text {th }}$ edn. Bailliere 176-180.

Yang and Deperra. 1998. The Plant Journal . John Wiley \& Sons. 14: 653-774.

\section{How to cite this article:}

Susmitha, S., R.Shyamala Gowri, P.Meenambigai, R.Ramitha and Vijayaraghavan, R. 2016. Physiochemical properties of purified Catalase enzyme from Azolla. Int.J.Curr.Microbiol.App.Sci.5(2): 836-844. doi: http://dx.doi.org/10.20546/ijcmas.2016.502.095 